\title{
Pure visual metaphor: Juri Lotman's concept of rhetoric in fine arts
}

\author{
Linnar Priimägi \\ Department of Advertising and Media, Tallinn Pedagogical University \\ 27 Narva St., 10120 Tallinn, Estonia \\ e-mail: tristan@tpu.ee
}

\begin{abstract}
Salvador Dalí's oilpainting Hallucination partielle. Six apparitions de Lénine sur un piano (1931) has been considered to be one of the most difficult works to interpret. O. Zaslavskii has analyzed it, using the sound of the words in title and the items depicted on the masterpiece, "the phonetic subtext". Obviously, Zaslavskii's interpretation is based on Osip Mandelstam's poem "Grand piano" (1931), that in the context of Russian language associates the piano (рояль) with the French Revolution. Nevertheless, Zaslavskii's final conclusion of the connections between Dalí's painting and the French Revolution turns to be accurate, because it is possible to find iconographic parallels between Dalí's "Partial hallucination..." and JacquesLouis David's "The death of Marat" (1793). On at least four most significant oil paintings from the beginning of Dalí's surreal period we can observe his "emblem of love and death" as the combination of fellatio and bleeding. Obviously, he understood in the same code also Marat's murdering by the knife of a woman. This allows us to insist, that Dalí was inspired to paint "Partial hallucination..." by "The death of Marat". The shadow of a grand piano on his painting "Diurnal illusion: the shadow of a grand piano approaching" (1931) directly bears the meaning of "terror" and "fear". In such motif combination and graphic parallel, the complex cultural metaphoric relations of these two paintings can be viewed. This complex can be considered as rhetorical in the sense of Juri Lotman's conception. But it is evidently a case of "pure visual metaphor", not an illustration of verbal metaphors.
\end{abstract}


In his article "Rhetoric" (1981) $)^{1}$ Juri Lotman presents a thorough overview of the essence of this concept in several scientific paradigm and amends it with his innovative approach to rhetoric as a science with a specific object.

We are interested in following of his theoretical distinctive characters. First: rhetoric is a "science of generating a text", "a compilation of rules, a generating mechanism", which has a practical (pragmatic, applied) orientation. Second: such rhetoric of "open text" that includes creation or generation of a text can be distinguished from the "closed text" rhetoric - poetics of a text as a whole, where texts are being analyzed in their entirety, "text as an entire semiotic unit" (Lotman 1992: 167).

The last can be possible because rhetoric as poetics of figurative word-text "melts together" the smaller units of the text. In such case, text as the bearer of the essential meaning is primary. In its nature, text is not discrete in its nature but continual. The meaning of a text as a whole is not shaped by the linear position of its segments or timeline but exists in a diffuse way in the text's $n$-dimensional semantic space (on a painting's canvas, on the stage, on screen, in ritual act, in social behavior or dream). In such kind of texts the meaning is conveyed by the very integrity of the text, whereas distinguishing single component marks is complicated and often artificial. In another language (i.e. continual figurative text) the "word text's" discrete and precisely specified unit corresponds to a vague meaning-spot that gradually is changing its meaning. And even if there is a sui generis segmentation, it can not be suited with the discrete articulation type of the source text (i.e. the word text) (Lotman 1992: 167).

\section{Salvador Dalí's “Partial hallucination. Six apparitions of Lenin on a grand piano"}

Spanish artist Salvador Dalí's works are clear in their form but complex in their essence. It can be felt that the author is trying to express something meaningful, but he does it in his own figurative language that is easier to notice than to understand. The audience standing in front of this master's artwork must feel as Polonius, when he mentioned to Hamlet: "Though this be madness, yet there is method in ' $t$ '.

\footnotetext{
${ }^{1}$ See Lotman 1992: 167-183.
} 
Salvador Dalî's oilpainting "Partial hallucination. Six apparitions of Lenin on a grand piano" (Fr. Hallucination partielle. Six apparitions de Lénine sur un piano, 1931; see Fig. 1) has been considered to be one of the most difficult works to interpret because it apparently combines several figures that were developed in Dalí's works during 1920/30.

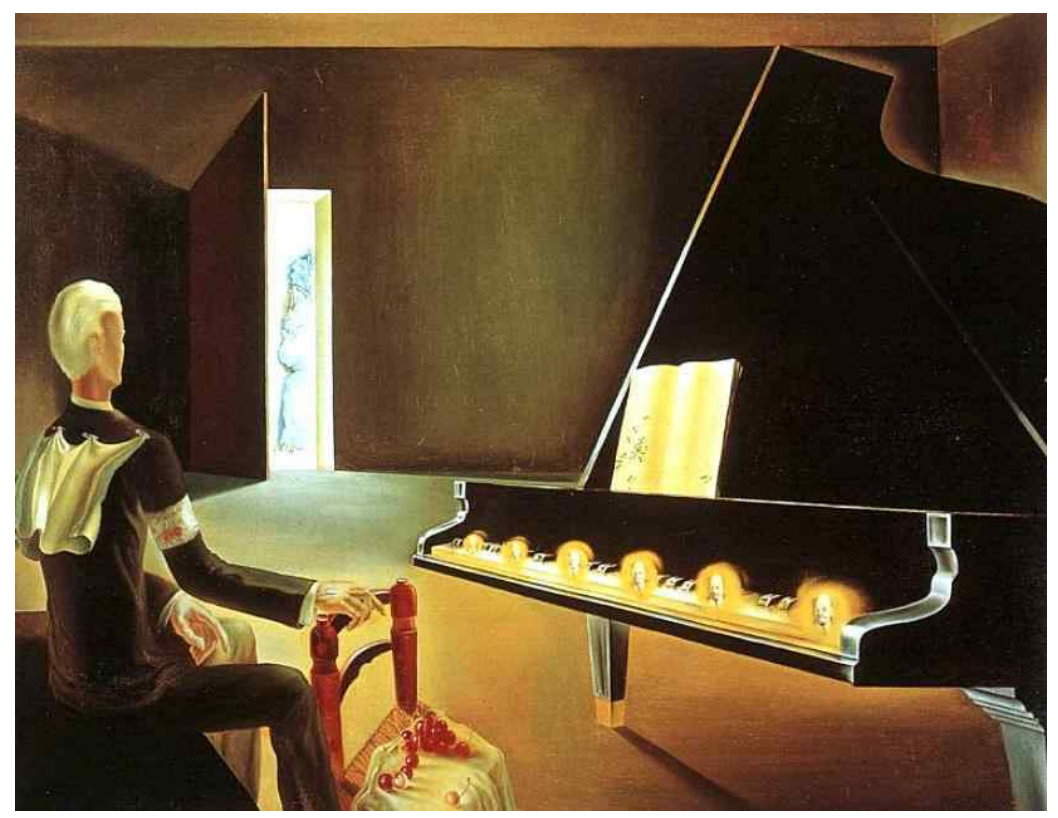

Figure 1. Salvador Dalí: 'Partial hallucination. Six apparitions of Lenin on the Grand Piano' (1931).

Art historians have been incapable here. On one hand, they have reached a precise correspondence of the elements, which is not characteristic to art and its multiple meanings: the cherries represent "the secret of branching"; the ants climbing up the music-book symbolize mortality, etc. On the other hand, the analysis of this artwork has been replaced with anecdotes of S. Dalí's life - the artist confessed to have seen the busts of Lenin on the piano during a walk at dawn. This neither has anything to do with art theory. 


\section{Oleg Zaslavskii's literary interpretation}

Oleg Zaslavskii from Harkov University has analyzed Dalí's painting "Partial hallucination. Six apparitions of Lenin on the grand piano", using the sound of the words in title and the items depicted on the masterpiece, "the phonetic subtext", including anagrams and similarities of the sound-components, as the key to decipher it (Zaslavskii 1999).

One has to admit that due to Russian-language background, at times O. Zaslavskii tends to come to arbitrary conclusions.

(a) For instance, in his interpretation Zaslavskii does not focus on the French word piano in the original Dalí's title but its Russian equivalent рояль that associates it with royalism.

(b) He bases on the Russian word галлюиинация instead of the French hallucination and accordingly claims the connection with gallicism (although in the source language the initial $h$ is not pronounced at all, not to mention the already gutturalized pronunciation) and based on the same word derives an anagram гильотина ("guillotine").

(c) Based on a Russian word черешня ("cherries") he suggests an English equivalent cherish, that has a completely different meaning.

(d) Presumably background of English (not French) language allows him to easily unite the French words porte (“door"), pronounced [port], and part ("part"), pronounced [pa:(r)t] in English, but [pa:r] in French.

As a result of his interpretation, O. Zaslavskii comes to an understanding that Dalí's painting depicts revolutionary terror.

Based on sound similarities, he forms following associative relations:

Rus. рояль ("piano") $\rightarrow$ Fr. royal ("royal"),

Fr. partielle ("partial") $\rightarrow$ party $\rightarrow$ Royalist party $\rightarrow$ pianist as royalist $\rightarrow$ the French Revolution $\rightarrow$ execution of the emperor $\rightarrow$ Russian Revolution $\rightarrow$ Lenin as the person who executed the czar $\rightarrow$ royalist sitting opposite to a revolutionist,

Rus. галлюиинация ("hallucination") $\rightarrow$ Rus. гильотина ("guillotine") $\rightarrow$ heads separated from bodies $\rightarrow$ piano lid as a guillotine,

bugs on the music $\rightarrow$ termites $\rightarrow$ Thermidor (collapse of Jacobin government),

Rus. партия рояля ("piano work") $\rightarrow$ Royalist party,

single bug apart from the others as well as single berry on the chair $\rightarrow$ disassembling head from the body,

red berries $\rightarrow$ blood,

napkin attached to a man's shoulder with safety pins (rus. английская булавка,

Fr. épingle anglaise — "English needle") $\rightarrow$ English Revolution $\rightarrow$ beheading of Charles I,

Engl. napkin $\rightarrow$ Engl. nape + Engl. king

Charles I $\rightarrow$ engl. chair $\rightarrow$ chair with the berries $\rightarrow$ throne,

Engl. chair $\rightarrow$ Engl. cherry, 
person sitting (pianist) as a king (Louis XVI or Charles I) $\rightarrow$ head of state $\rightarrow$ V. I.

Lenin as a head of a revolutionary state, sixteen berries $\rightarrow$ Louis XVI,

1 single berry $\rightarrow$ Charles I,

6 apparitions of Lenin $\leftarrow 16$ without 1 ,

6 apparitions of Lenin $\leftarrow 7$ notes in an octave $\rightarrow$ seventh head of Lenin missing $\rightarrow$ beheading,

halation around Lenin's head $\rightarrow$ fruit's flesh around the bone $\rightarrow$ "fruits of revolution",

napkin on the shoulders of the sitting person instead of the king's gabardine $\rightarrow$ Engl. linen $\rightarrow$ anagram: "Lenin",

Fr. porte ("door") $\rightarrow$ Fr. part ("part") $\rightarrow$ Fr. partielle ("partial”) $\leftarrow$ door partially open.

Obviously, such an interpretation by Zaslavskii is not originally based on Dalí's work but on Russian poet Osip Mandelstam's writings, specifically on his poem "Grand piano" (1931; Mandelstam 1999: 142):

РОЯЛЬ

Как парламент жующий фронду,

Вяло дыиит огромныий зал,

Не идет Гора на Жиронду,

И не крепнет сословий вал.

Оскорбленный и оскорбитель

Не звучит рояль-Голиаф,

Звуколюбеи, душемутитель,

Мирабо фортепьянных прав.

Разве руки мои кувалдыл?

Десять пальиев - мой табунок!

И вскочил, отряхая фалды,

Мастер Генрих, конек-горбунок.

[...]

Чтобы в мире стало просторней,

Ради сложности мировой,

Не втирайте в клавиши корень

Сладковатой груши земной.

Чтоб смолою соната джина

Проступила из позвонков,

Нюренбергская есть пружсина,

Выпрямляюшая мертвецов.

This is a complicated text with deep and actual biographic background. The poet's mother was a musician, and literary historian Zara 
Grigorievna Mints has described the respect of piano in the Mandelstam family (they were not allowed to place anything as profane as newspapers on the piano). The text is also dated (as it was a habit of poets in 1930s): April 16, 1931.

What exactly happened on April 16 is irrelevant from the aspect of S. Dalí's painting. What is important is that O. Zaslavskii's interpretation is - perhaps unconsciously — guided by O. Mandelstam's poem, that in the context of Russian language associates the piano (рояль) with the anti-royalist history of France (фронду — "Fronde") and the French Revolution (Гора — "Mountain", Жиронду — "Gironde", Мирабо — "Mirabeau").

Led by O. Mandelstam (and his death in a Siberian forced labor camp during Stalinist terror period), O. Zaslavskii concludes that with his painting S. Dalí "condemns totalitarianism from aesthetical positions".

However, O. Zaslavskii's political interpretation can not be backed up by claims about Dalí's knowledge of English and Russian language nor his alleged anti-totalitarian views.

Dalí was likely to represent contrary views, total or totalitarian artist concept - he saw himself as the art monarch of XX century (Fig. 2). Louis XVI (1643-1715), the notorious Sun King who validated absolute monarchy in France, was a great raw-model for Dalí (Fig. 3).

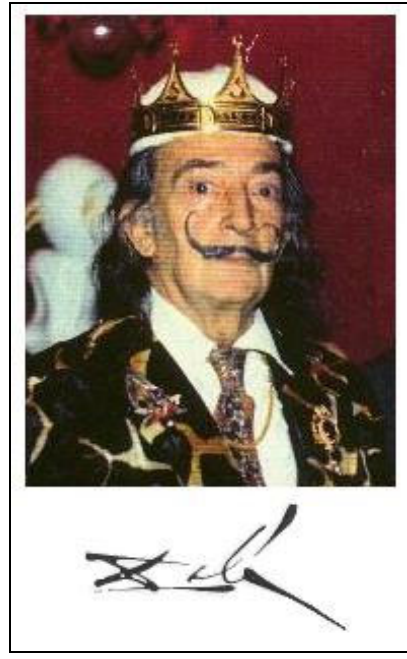

Figure 2. Salvador Dalí with a crown.

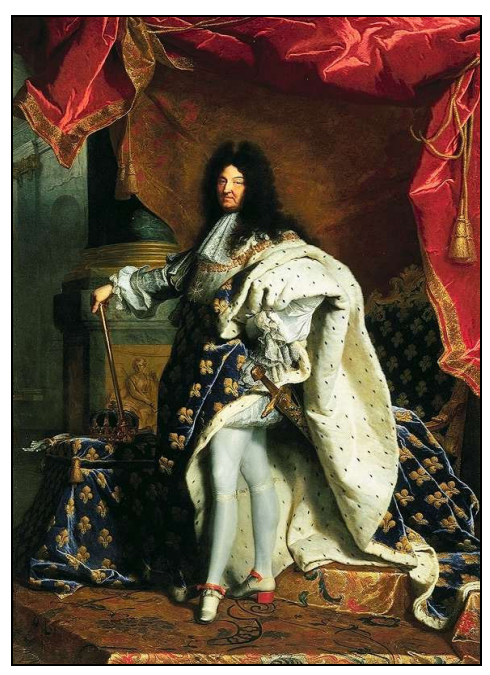

Figure 3. Hyacinthe Rigaud: Roi soleil Louis XIV (1701). 
“The Sun King” is depicted on S. Dalí's watercolor (see Fig. 4); also, his perfume for men and women bears the name "Le Roy Soleil" (Fig. $5)$.

Dali is obviously in favor of absolute monarchy and totalitarianism, not condemning it. This allows us to reject O. Zaslavskii's interpretation.

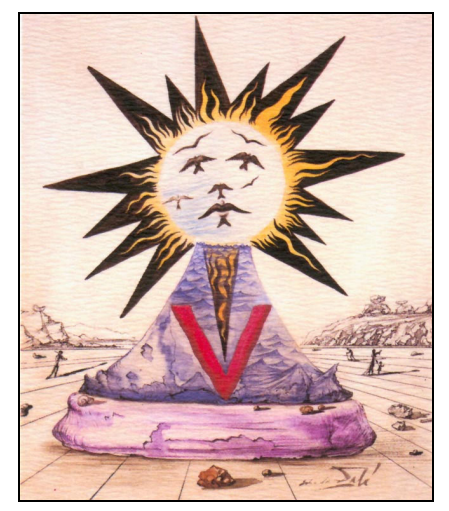

Figure 4. Salvador Dalí: 'Le Roy Soleil' (ca. 1944).

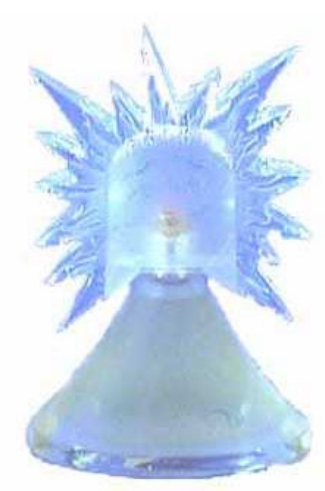

Figure 5. Perfume bottle of "Salvador Dalí: Le Roy Soleil".

\section{Iconographical key: Jacques-Louis David's "The death of Marat" (1793)}

Nevertheless, O. Zaslavskii's interpretation must be recognized as the most prominent attempt to date to find an intentional center of the depicted objects, a central idea towards which the seemingly incoherent objects of the painting are gravitating.

His final conclusion of the connections between Dalí's painting and the French Revolution turns to be accurate, because it is possible to find visual parallels between Dalí's "Partial hallucination..." and "the revolutionary court-artist" Jacques-Louis David's "revolutionary icon" _ "The death of Marat" (1793) (Fig. 1 and 6, Table 1). 


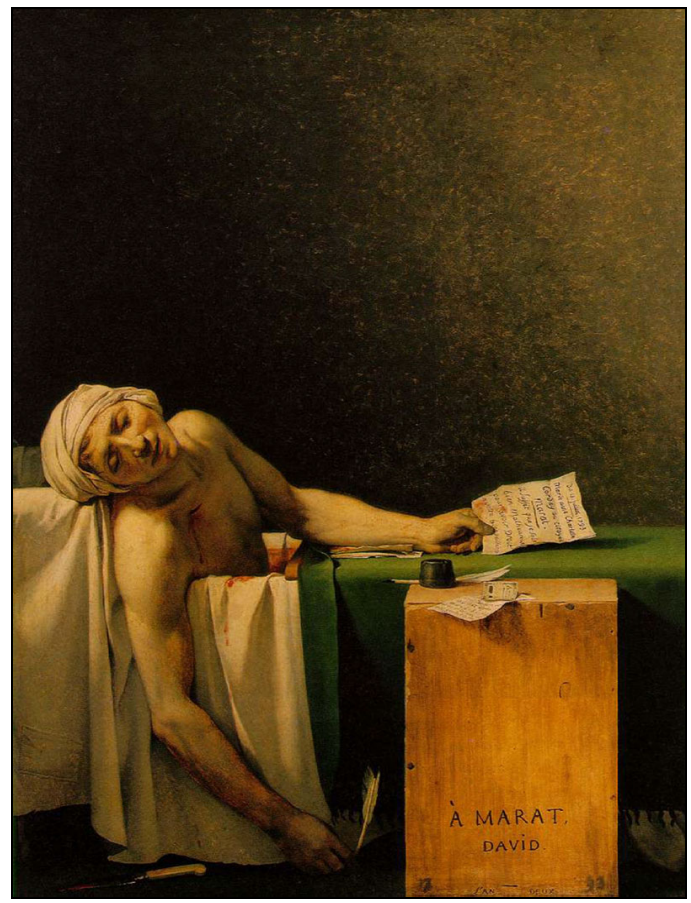

Figure 6. Jacques-Louis David: The death of Marat (1793).

Table 1. Comparison of the paintings' iconography.

\section{S. Dalí \\ "Partial hallucination..."}

blank back wall

arc of the piano lid

empty floor

right arm in the foreground

a mummy-like person

blonde helmet haircut

napkin on the back

music book on the piano

open piano

a chair

(blood-red) berries

Lenin's images on the piano

\section{J.-L. David \\ "The death of Marat"}

blank back wall

arc of shadow on the back wall

blank faceplate of the podium

right arm in the foreground

dead person

headscarf

a towel

letter in left hand

a bath tub

a podium

pot of ink (which is used for writing bloody or passionate revolutionary regulations)

money note (assignat) on the podium (compare to Fig. 7) 


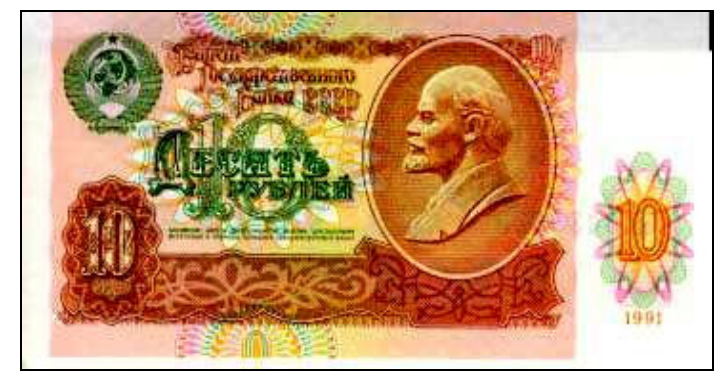

Figure 7. A bank note with V. I. Lenin's portrait.

If taking into consideration the similarity of the greenish-brown colour that is even matching occasionally (back wall, floor and podium), the connections of the Socialist October Revolution and the French Revolution on S. Dalí's painting can be verified visually, not by just verbal associations.

\section{The meaning field of a metaphor}

Such comparison is explained with S. Dalí's motif story in 1929/1931, where the combination of fellatio and bleeding becomes his "emblem of love and death" and the grand piano is featured in a specific meaning.

We can observe these motifs on at least four S. Dalí's most significant oil paintings from the beginning of his surreal period:

"The great masturbator" (1929, Fig. 8),

"The enigma of desire: my mother, my mother, my mother" (1929, Fig. 9),

"Vertigo" (1930, Fig. 10), and

"Diurnal illusion: the shadow of a grand piano approaching" (1931, Fig. 11). 


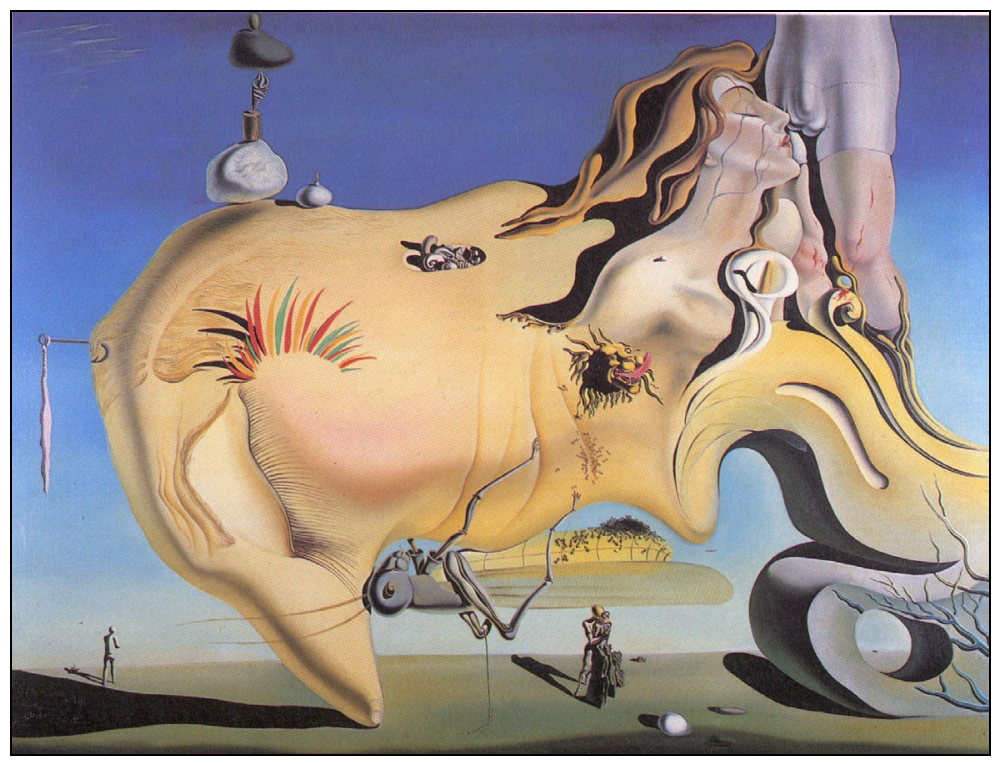

Figure 8. Salvador Dalí: 'The great masturbator' (1929).

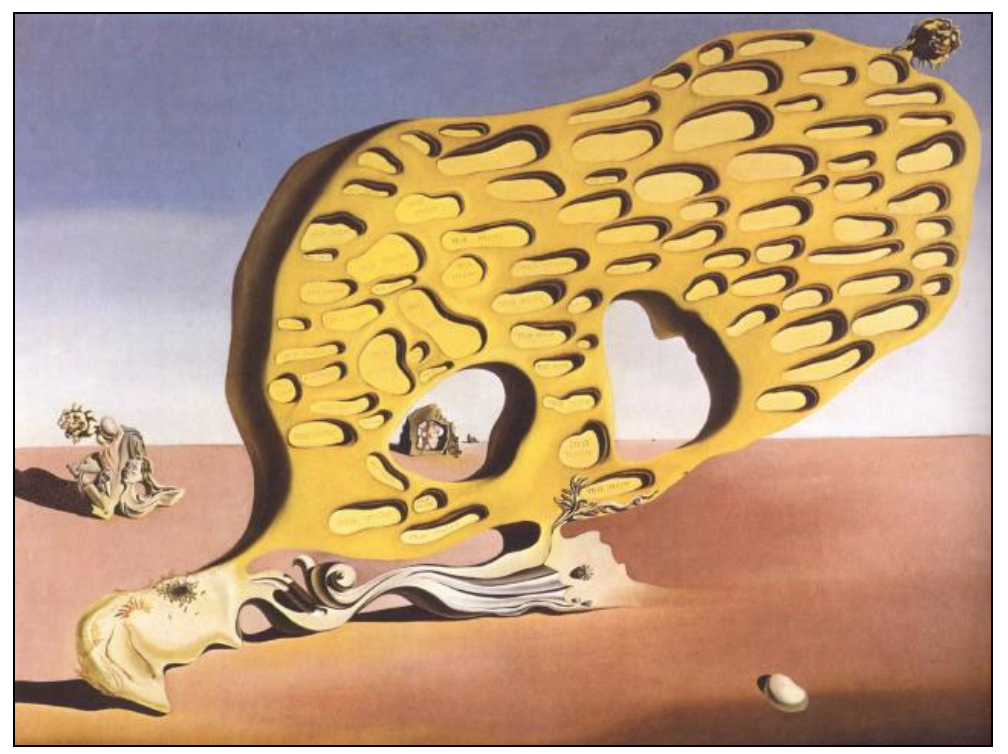

Figure 9. Salvador Dalí: 'The enigma of desire: my mother, my mother, my mother (1929). 


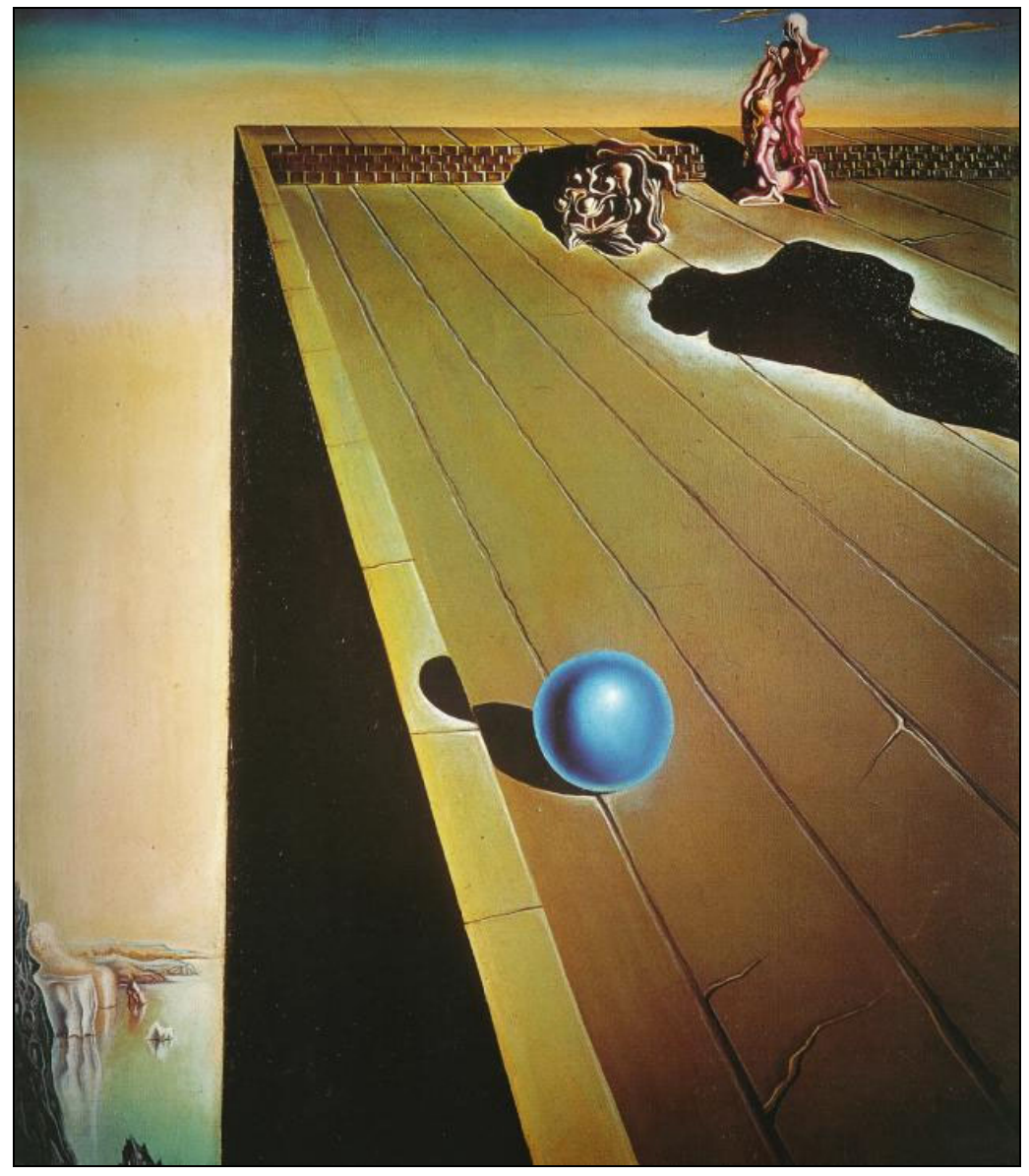

Figure 10. Salvador Dalí: 'Vertigo’ (1930). 


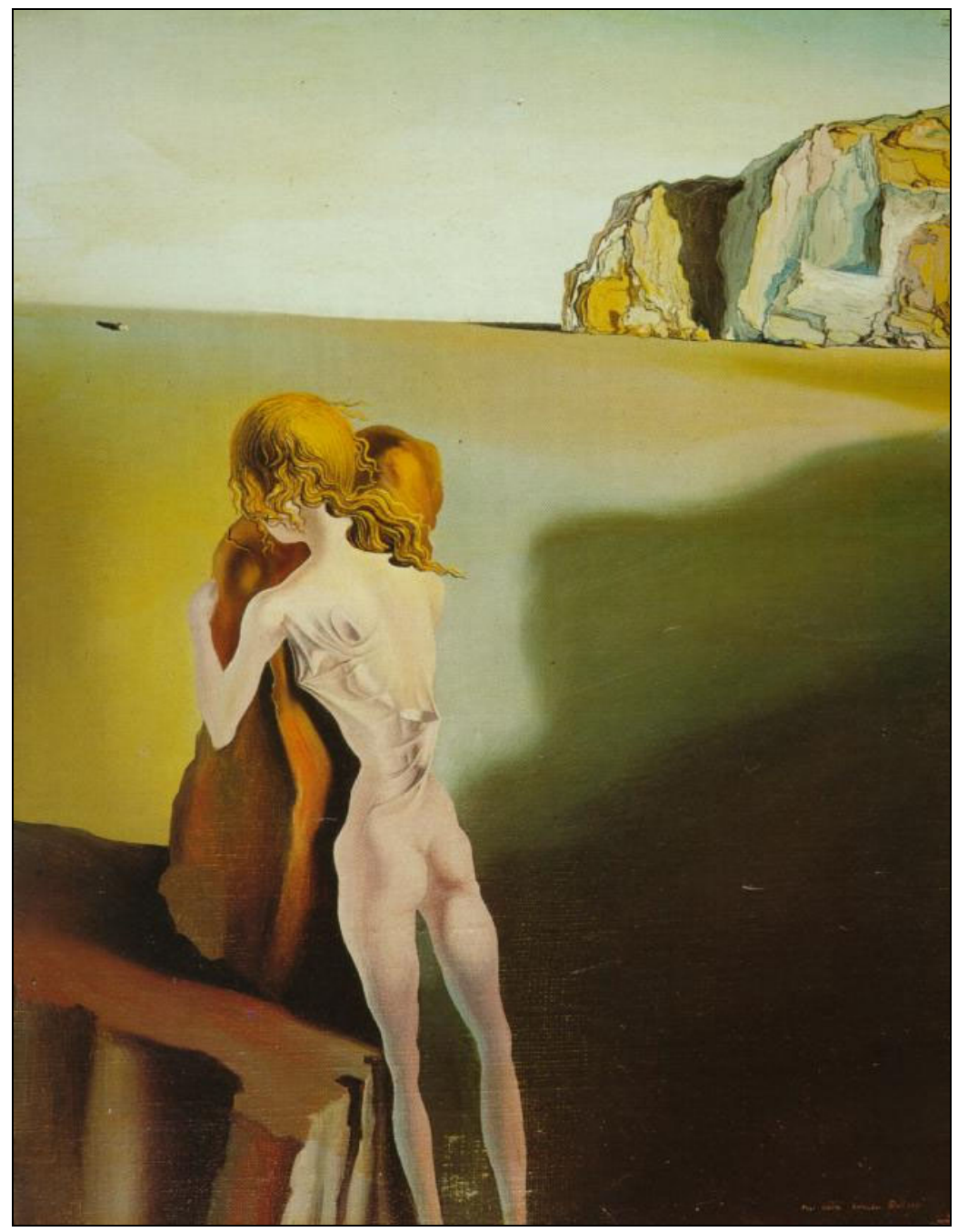

Figure 11. Salvador Dalí: 'Diurnal illusion: the shadow of a grand piano approaching' (1931). 


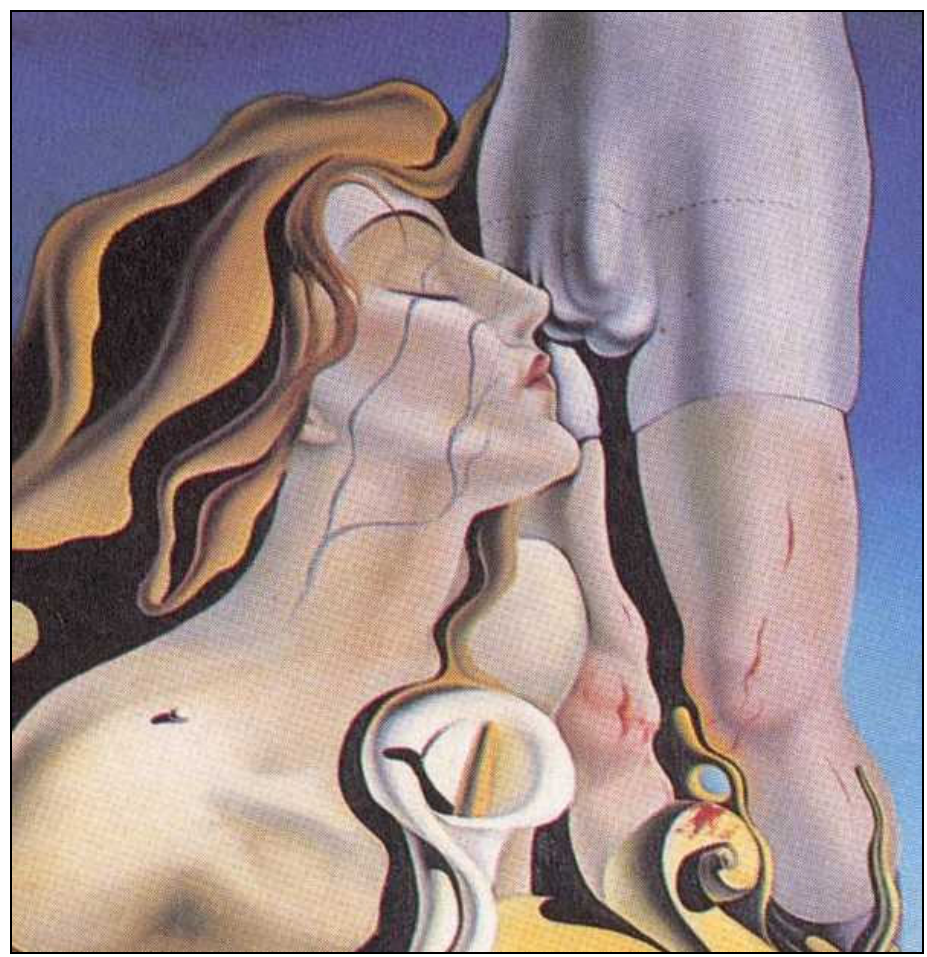

Figure 12. Salvador Dalí: 'The Great Masturbator' (detail).

The upper right part of S. Dalí's “The great masturbator" depicts the beginning of a fellatio act (Fig. 12). The red blood marks on the man's thighs are probably scratch marks, which associate the woman's nails with knives.

In "The enigma of desire: my mother, my mother, my mother", painted the same year, a female figure embracing a man's lower body on the background of the painting, is holding already clearly identifiable knife (Fig. 13). 


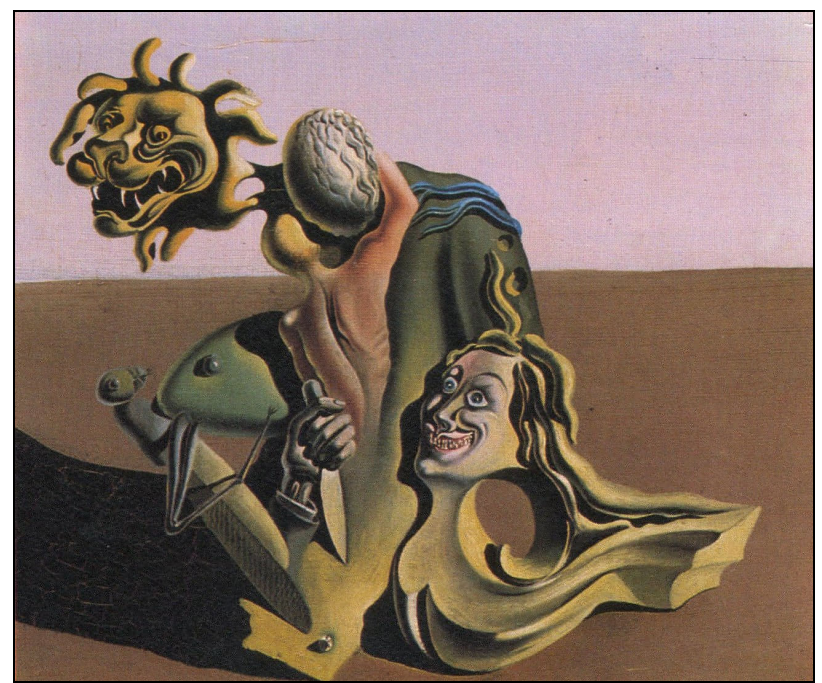

Figure 13. Salvador Dalí: 'The enigma of desire: my mother, my mother, my mother' (detail).

The connection between fellatio and stabbing becomes even clearer with "Vertigo" painted the following year with its group of people on the background on the right (Fig. 14).

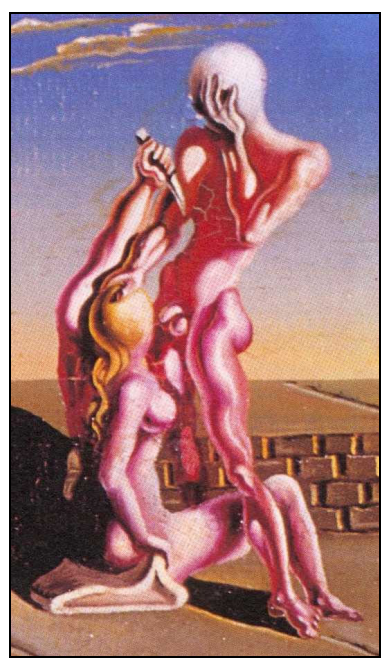

Figure 14. Salvador Dalí: 'Vertigo' (detail). 
Fellatio combines death with hate-like love, a complex that S. Dalí was focused on during that period. He probably understood the stabbing motif in J.-L. David's "The death of Marat" in the same key, as the stabber was a woman - Charlotte Corday. Iconographic isomorphism allows us to insist, that S. Dalí was inspired to paint "Partial hallucination..." by "The death of Marat".

Another iconographic parallel from S. Dalí's same period can affirm that argument. "Diurnal illusion: the shadow of a grand piano approaching" painted the same year as "Partial hallucination...", depicts the instrument as something horrible, huge, grand and heavy threateningly nearing, with the scared people looking for support from each other. The "shadow" here bears the meaning of "terror" ("fear"), that definitely is a part of J.-L. David's painting, dating back to the Jacobin terror (tyranny) period and which also applies - due to graphic similarities — to S. Dalí's painting "Partial hallucination...".

In such motif combination and graphic parallel, the complex cultural metaphoric relations of S. Dalí's "Partial hallucination. Six apparitions of Lenin on the grand piano" and J.-L. David's "The death of Marat" can be viewed. This relationship is spread on the painting as a whole through single isomorphisms (S. Dalí's painting is a metaphor of J.-L. David's painting) and has to be considered rhetoric in the light of Juri Lotman's rhetorics concept.

Juri Lotman already pointed in the year 1973 to the habit to see in verbal communication the main or even the only form of the communicative contact and to equate the picture text with the verbal one (Lotman 1973: 382-386). S. Dalí's "Partial hallucination..." can be seen as a case of pure visual metaphor, not a figurative illustration of verbal metaphors.

\section{References}

Lotman, Yu. M. 1973. Zamechaniya o strukture povestvovatel'nogo teksta. Sign Systems Studies (Trudy po znakovym sistemam) 6: 382-386.

- 1992. Izbrannye stat'i v treh tomah, t. 1. Tallinn: Aleksandra.

Mandelstam, Ossip 1983. Hufeisenfinder: Russisch und deutsch. Leipzig: Philipp Reclam jun.

Zaslavskii, Oleg 1999: Obrazno-yazykovyj analiz totalitarizma v dvuh "leninskih" kartinah Dali. Sign Systems Studies 27: 168-175. 


\section{Чистовизуальная метафоричность. Риторическая концепция Юрия Лотмана в изобразительном искусстве}

Картина «Частичная галлюцинация. Шесть явлений Ленина на рояле» (1931, см. иллюстрацию 1) считается одной из самых труднообъяснимых в творчестве Сальвадора Дали. Олег Заславский предпринял ее анализ («Образно-языковой анализ тоталитаризма в двух «ленинских» картинах Дали», Sign Systems Studies 27: 168-180), исходя из «фонетического подтекста» как слов заглавия, так и словесных обозначений вещей, изображенных на картине. Но из-за русскоязычного фона он опирается не на слово piano во французском оригинале, а на его русскоязычное соответствие рояль, что позволяет ему ввести параллель с роялизмом. Видимо за этим стоит цитируемое им стихотворение Осипа Мандельштама «Рояль» (1931), которое прямо связывает рояль с антироялистским движением во Франции ("Fronde") и еще более - с Великой французской революцией (“Гора”, “Жиронда”, “Мирабо”).

Тем не менее, вывод Заславского о связи картины Дали с французской революцией оказывается верным, так как можно провести иконографические параллели между "Частичной галлюцинацией..." С. Дали и "Смертью Марата" (1793) Жак-Луи Давида (см. иллюстрацию 6): пустынный фон, дуга поднятой крышки рояля - дуга тени на задней стене, на первом плане правая рука, мумиеподобный сидящий - мертвец, светлая шлемеподобная прическа - полотенце вокруг головы, салфетка на спине - банница, нотные страницы на пианино - письмо в левой руке, открытое пианино - ванна, стул - пюпитр для писем, изображения Ленина на пианино - денежная ассигнация на пюпитре. Если еще учесть похожесть и частичную совпадаемость зелено-коричневого колорита (задняя стенка, пол и пюпитр), то связь Великой октябрьской революции с Великой буржуазной французской революцией на картине Дали кажется вполне оправданной, исходя из визуальной стороны картины.

На пороге 1920/30-х годов Дали еще в трех известных картинах (“Великий мастурбатор”, “Загадка желания - моя мать, моя мать, моя мать", "Вертиго") изображал комплекс любви-ненанвисти, связывая фелляцию и смерть. Видимо, в этом же ключе он понимал и пронзенного рукой женщины Марата. Это позволяет утверждать, что Дали при создании "Частичной галлюцинации" вдохновлялся именно "Смертью Марата" Давида. Прибавим, что тень рояля на его картине "Дневное видение. Приближающая тень большого рояля" (1931) связывается прямо со страхом и террором.

В таком мотивном сосушествовании и графическом параллелизме проявляется сложная культурологическая метафорическая связь двух картин, которую можно считать риторической в свете риторической концепции Юрия Лотмана. Но в данном случае мы имеем дело со случаем чистовизуальной метафоричности, а не с иллюстрацией вербальных метафор. 


\section{Puhtvisuaalne metafoorsus: Juri Lotmani retoorikakontseptsioon kujutavkunstis}

Õlimaali "Osaline kangastus. Kuus Lenini ilmumit tiibklaveril" (1931, Joon. 1) on peetud üheks Salvador Dalí kõige raskemini seletatavaks teoseks. Oleg Zaslavskii on analüüsinud seda, võttes teose võtmeks nii pealkirja kui ka pildil kujutatud asju tähistavate sõnade kõla, "foneetilise allteksti”. Emakeelse tausta tõttu ei lähtu ta aga mitte prantsuskeelse originaalpealkirja sõnast piano, vaid selle venekeelsest vastest рояль, mis annab talle seose rojalismiga. Ilmselt on selle taga Ossip Mandelštami luuletus "Tiibklaver" (1931), mis otsesõnu seostab klaveri (рояль) Prantsusmaa antirojalistliku ajalooga ("Fronde") ja lähemalt Suure Kodanliku Prantsuse revolutsiooniga ("Mägi", "Gironde", "Mirabeau").

Kummati osutub O. Zaslavskii lõppjäreldus S. Dalí maali seotusest Prantsuse revolutsiooniga õigeks, sest võimalik on leida ikonograafilisi paralleele $S$. Dalí "Osalise kangastuse..." ja Jacques-Louis Davidi "Marat' surma" (1793) vahel (Joon. 1 ja 6, Tabel 1): lage foon, klaverikaane kaar — varjukaar tagaseinal, esiplaanil parem käsi, muumialaadne istuja - surnu, hele kiiversoeng — rätt ümber pea, salvrätik selja taga - vannilina, noodilehed klaveril - kiri vasakus käes, avatud klaver - vann, tool - kirjutuspoodium, Lenini näopildid klaveril — rahatäht (assignaat) poodiumil. Kui arvestada veel rohekaspruuni koloriidi sarnasust ja kohatist kattuvustki (tagasein, põrand ja poodium), siis paistab Suure Sotsialistliku Oktoobrirevolutsiooni seos Suure Kodanliku Prantsuse Revolutsiooniga S. Dalí maalil põhjendatud pildiliselt.

1920/30. aastate vahetusel kujutas S. Dalí veel kolmes tuntud teoses ("Suur masturbaator", "Iha mõistatus - mu ema, mu ema, mu ema", "Vertigo") vihkamisseguse armastuse kompleksi, seostades fellatsiooni ja surma. Ilmselt mõistis ta sellessamas võtmes ka Marat' pussitamist naise käe läbi. See lubab väita, et S. Dalî'd inspireeris "Osaliseks kangastuseks..." just J.-L. Davidi "Marat' surm". Lisagem, et klaveri vari tema maalil "Päevane heiastus. Suure klaveri liginev vari" (1931) seostub otseselt hirmu ja terroriga.

Säärases motiivikoosluses ja graafilises parallelismis ilmneb kahe maali keeruline kultuurilooline metafoorsussuhe, mida tuleb lugeda retooriliseks Juri Lotmani retoorikakontseptsiooni tähenduses. Tegemist on aga puhtvisuaalse metafoorsuse juhtumiga, mitte verbaalsete metafooride illustratsiooniga. 